\title{
RECTAL METHOHEXITONE FOR INDUCTION OF ANAESTHESIA IN CHILDREN
}

\author{
G.V. Goresky and D.J. Steward
}

Methohexitone (Brietal ${ }^{\oplus}$, Brevital ${ }^{*}$ ) $(\alpha$-dlmethyl-5[1 methyl-2 pentynyl] 5 allyl-barbituric acid) is an ultra short acting barbiturate. ${ }^{1}$ It is frequently used for intravenous induction of anaesthesia, ${ }^{2}$ but has also been recommended for intramuscular use. ${ }^{3}$ Rectal administration of this drug was suggested by Stetson, ${ }^{4}$ but this practice has not been widespread, possibly because of the unpredictable effects of other barbiturates when given by this route.

Recovery following methohexitone is reported to be more rapid than that which follows thiopentone, ${ }^{2,5.6}$ and this is thought to be due to both a rapid redistribution of the drug and rapid metabolism.? Absence of a residual "hang-over" is considered due to a low oil-water partition coefficien ${ }^{8}$ which results in relatively little of the drug being retained in fat depots. More recent reports 9 of the satisfactory effects of rectal methohexitone in producing rapid reliable hypnosis in children led us to conduct a trial of this agent in a series of paediatric outpatients.

\section{Methods}

Eighty-three children, aged six months to five years, were studied. Thirty-six of these patients had anaesthesia induced by rectal methohexitone, the remainder with intravenous thiopentone. No patient received premedication. The methohexitone was administered in a room adjacent to the outpatient operating rooms.

Methohexitone was dissolved in sterile distilled water to make a 10 per cent solution and was administered in a dose of $25 \mathrm{mg} \cdot \mathrm{kg}^{-1}$ through a lubricated 14-gauge plastic suction catheter. A small amount of air was then injected through the catheter to flush the whole measured dose into

G.V. Goresky, M.D., F.R.C.P.(C), Lecturer, Department of Anaesthesia, University of Toronto, Staff Anaesthetist, The Hospital for Sick Children, Toronto, Ontario.

D.J. Steward, M.B., F.R.C.P.(C), Professor, Department of Anaesthesia, University of Toronto, Anaesthetist-in-Chief, The Hospital for Sick Children, Toronto, Ontario.

Mailing address: Dr. D.J. Steward, Anaesthetist-inChief, The Hospital for Sick Children, 555 University Avenue. Toronto, Ontario, Canada, M5G IX8.

Canad. Anaesth. Soc. J., vol. 26, no. 3, May 1979 the patient. The time between drug administration and the onset of a sound sleep was noted, as was the incidence of complications during induc. tion. After rectal administration of the drug and until sleep ensued, the child was nursed by the parent with the anaesthetist in attendance. Means to establish an artificial airway and to control ventilation were discreetly at hand. Once the patient was asleep he was rapidly moved to the operating room and anaesthesia was continued with nitrous oxide and halothane. Maintenance of andesthesia for the planned surgical procedure was with these same two agents.

After the operation had been completed the patient was allowed to awaken and was transferred to the post-anaesthesia room (P.A.R.). Here recovery from anaesthesia was documented using our own post-anaesthesia recovery scoring system. ${ }^{10}$ On discharge home from the P.A.R., usually after 60 to 90 minutes, a questionnaire was handed to the parents. This enabled us to collect information about the patient's progress at home, and particularly about his return to a normal "bright and alert" status and a normal appetite.

Recovery from anaesthesia in the P.A.R. and at home was compared to 47 patients who had anaesthesia induced with intravenous thiopentone $\left(5 \mathrm{mg} \cdot \mathrm{kg}^{-1}\right)$ but were otherwise treated in exactly the same way. Subsequent inhalation anaesthesia with halothane was of similar duration ( $25 \pm 5$ minutes) in both groups.

\section{RESUlts}

\section{Time to sleep}

The time required for onset of deep sleep in patients receiving methohexitone is shown in Figure 1. The range is 4 to 22 minutes with a mean of 8.6 minutes. Most patients were asleep in 6 to 11 minutes.

\section{Complications}

Complications which occurred during induction using rectal methohexitone are listed in Table I. Depression of ventilation requiring assisted ventilation is rare, bul occurred in one of 213 


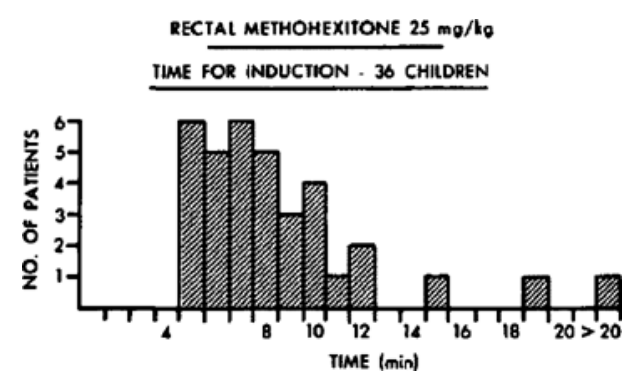

Ficure 1 Time of onset of deep sleep in 36 patients given rectal methohexitone $25 \mathrm{mg} \cdot \mathrm{kg}^{-1}$.

TABLE I

Complications During Induction (36 patients)

\begin{tabular}{ll}
\hline \hline Respiratory depression & 1 \\
Hiccoughs & 3 \\
Soiling & 3 \\
No sleep & 1 \\
\hline
\end{tabular}



Figure 2 Recovery room scores in the two groups of patients. Time is taken from admission to the recovery room. Based on the simplified scoring system ${ }^{10}$ which assigns points for return of consciousness, recovery of airway control and voluntary movement. A score of six indicates full return to consciousness, the presence of normal airway control and voluntary movement.

ventilation must always be close at hand and the patient must never be left unattended after the drug has been administered. Hiccough may occur, as it does also after intravenous methohexitone, and was seen in three of our patients (approximately eight per cent).

\section{Recovery}

Recovery of each group in the post-anaesthetic room is compared in Figure 2. Though the score

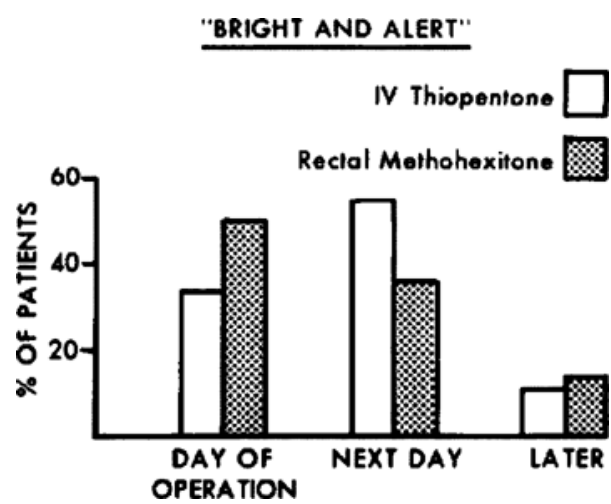

Figure 3 Time of return to a normal "Bright and alert" status at home in 36 patients given rectal methohexitone compared with 47 patients induced with intravenous thiopentone.

\section{RETURN TO NORMAL APPETITE}



Figure 4 Time of return to a normal appetite at home in 36 patients given rectal methohexitone compared with 47 patients induced with intravenous thiopentone.

for the methohexitone group is lower after 15 minutes, by 30 minutes postoperatively there is no difference between the groups.

Recovery at home is shown in Figures 3 and 4. Return to a normal "bright and alert" status and a normal appetite was similar in both groups, and there is no evidence that rectal methohexitone caused any delay in recovery at home.

The incidence of nausea and vomiting was similar in both groups.

\section{Discussion}

The selection of a technique for the induction of anaesthesia in children requires careful consideration. The child must be upset as little as possible, as a traumatic induction of anaesthesia 
may have lasting psychological effects. Apart from the young infant (under three months) many children will not accept a mask induction unless heavy doses of premedication have been administered. Such heavy premedication is contra-indicated for the out-patient and also for many other paediatric patients. "Recovery Delirium" is commoner following large doses of premedicant drugs.

Intravenous induction is preferred for most older children (over three years) and has been demonstrated to cause less immediate and delayed emotional disturbance." However, this is more difficult in those who are younger and uncooperative. More important, it is difficult to explain to young children what is going to happen and that you are not going to hurt them.

Rectal barbiturate offers a relatively noninvasive induction of anaesthesia for the young age group (three months to three years) Thiopentone has been used by this route but has never gained wide acceptance due in part to its unpredictable effect. We have found that methohexitone given rectally produces quite reliable results, though occasionally sleep may be delayed for up to 20 minutes. Only very rarely did the child not fall asleep, but was then at least very well sedated and would readily accept an inhalation induction. Recovery after the operation is not markedly prolonged when compared with those children who received intravenous thiopentone for induction. Our results do not indicate that there are any delayed effects of the methohexitone in prolonging recovery to a normal status at home. This might be expected in view of the rapid metabolism of the drug and its low fat solubility.

The complication rate associated with the use of rectal methohexitone is low, but because of the risk of respiratory obstruction or depression, means of airway support and ventilation must always be immediately available.

We limited our use of rectal methohexitone to those patients who are less than five years of age. Older children can be managed readily with intravenous induction and may, indeed, be much more disturbed by rectal administration of drugs than by a painless skillful venipuncture.

\section{Conclusions}

Rectal induction of anaesthesia using ten per cent methohexitone is a safe and effective method for young children. It is particularly applicable to the child three months to four years of age. Twenty-five $\mathrm{mg} \cdot \mathrm{kg}^{-1}$ of methohexitone should be given and the child should be observed continuously by the anaesthetist until he falls asleep. Equipment to establish an artificial airway and to ventilate the lungs should be immediately at hand. The use of rectal methohexitone does not significantly delay immediate or late recovery after short (30-minute) surgical procedures.

\section{RÉSUMÉ}

L'induction du jeune enfant au moyen de méthohexital administré par voie rectale s'est avérée une méthode efficace et sécuritaire. Elle est particulièrement à recommander chez l'enfant de trois mois à cinq ans. Une solution aqueuse à dix pour cent est administrée à la dose de $25 \mathrm{mg}$ par kilogramme. L'anesthésiste doit surveiller l'enfant de façon continue depuis le moment où il administre le barbiturique et doit avoir à portée de main un nécessaire à intubation et à ventilation. L'éveil n'est pas retardé de façon significative par rapport à une induction intraveineuse au thiopenthal et les effets tardifs sont comparables lors d'interventions chirurgicales de moins de 30 minutes.

\section{REFERENCES}

1. WhitwaM, J.G. Editorial - Methohexitone. British Journal of Anaesthesia 48: 617-619 (1976)

2. Whitwam, J,G. \& Manners, J.M. Clinical comparison of thiopentone and methohexital. British Medical Journal I: 1663-1665 (1962).

3. Elman, D.S. \& Denson, J.S. Pre-anaesthetic sedation of children with intramuscular methohexital sodium. Anesthesia \& Analgesia 44: 494-498 (1965).

4. STETson, J.B. Unpublished Data.

5. Barry, C. T., Lawson, R., \& Davidson, D.G.D. Recovery after methohexitone and thiopentone. Anaesthesia 22: 228-234 (1967).

6. Carson, I.W. Graham, J., \& Dundee, 3.W Clinical studies of induction agents. XLIII. Recovery from althesin - a comparative study with thiopentone and methohexitone. British Journal of Anaesthesia 47: 358-364 (1975).

7. MURPHY, P.J. Biotransformation of methohexital. International Anesthesiology Clinics.

8. Brand, L., Mark, L.C., Snell, M.M., VrindTEN, P., \& DAYTON, P.G. Physiologic disposition of methohexital in man. Anesthesiology 24: $331-335$ (1963).

9. RYan, J.F. Personal communication.

10. STEWARD, D.J. A simplified scoring system for the postoperative recovery room. Canadian Anaesthetists ${ }^{+}$Society Journal 22: $111-113$ (1975).

11. KAY, B. Out-patient anaesthesia, especially for children. Acta Anaesthesiol. Scand. Suppl. 25: 421-425 (1966) 